\title{
Return on Equity, Debt to Equity Ratio, Price Earning Ratio, Assets Growth, Inflasi dan Return Saham Perusahaan Property dan Real Estate
}

\author{
Eka Budi Yulianti', Suratno ${ }^{2}$ \\ ${ }^{1}$ Universitas Pancasila, Jl. Srengseng Sawah, Jagakarsa, Jakarta Selatan 12640
}

\author{
JEL Classification \\ G10 \\ F62
}

\section{Keywords :}

return on equity, debt to equity ratio, price earning ratio, asset growth, inflation, and stock return.

\section{A B S T T R A C T}

This paper aims to analyze return on equity, debt to equity ratio, price earning ratio, asset growth, and inflation on stock return on Property and Real Estate companies. Sample collection techniques in this study is purposive sampling to produce 25 samples property and real estate companies. The data required in this study were obtained from the Indonesian Capital Market Directory (ICMD , Indonesia Stock Exchange (IDX) and Bank Indonesia (BI). Data analysis method used is multiple linear regression using SPSS. The study concluded that simultaneous return on equity, debt to equity ratio, price earning ratio, asset growth, and inflation significant effect on stock return. While the partial test results show return on equity, price earning ratio, and inflation significant effect on stock return and debt to equity ratio and assets growth does not significantly affect the stock return .The results of this study indicate that the return on equity, price earning ratio, and inflation are used by investors to predict the stock return of property and real estate company listed on the Indonesia Stock Exchange 2007-2012 period.

\section{A B S T R A K}

Penelitian ini dilakukan untuk menguji return on equity, debt to equity ratio, price earning ratio, assets growth, dan inflasi terhadap return saham pada perusahaan property dan real estate. Teknik pengambilan Sampel dalam penelitian ini adalah purposive sampling sehingga menghasilkan 25 sampel perusahaan property dan real estate. Data yang diperlukan dalam penelitian ini diperoleh dari Indonesian Capital Market Directory (ICMD), Bursa Efek Indonesia (BEI) dan Bank Indonesia (BI). Metode analisis data yang digunakan adalah Regresi Linear Berganda dengan program SPSS. Hasil penelitian menyimpulkan bahwa secara simultan return on equity, debt to equity ratio, price earning ratio, assets growth, dan inflasi berpengaruh signifikan terhadap return saham. Sedangkan hasil pengujian secara parsial menunjukkan return on equity, price earning ratio, dan inflasi berpengaruh signifikan terhadap return saham dan debt to equity ratio dan assets growth tidak berpengaruh secara signifikan terhadap return saham. Hasil penelitian ini menunjukkan bahwa return on equity, price earning ratio, dan inflasi yang digunakan oleh investor untuk memprediksi return saham perusahaan Property dan Real Estate yang terdaftar di Bursa Efek Indonesia periode 2007-2012. 


\section{Pendahuluan}

Bisnis property dan real estate adalah bisnis yang dikenal memiliki karakteristik cepat berubah (volatile), persaingan yang ketat, persisten,dan kompleks. Kenaikan harga properti disebabkan karena harga tanah yang cenderung naik, dan supply tanah bersifat tetap sedangkan demand nya akan selalu bertambah besar seiring dengan pertambahan jumlah penduduk serta bertambahnya kebutuhan manusia akan tempat tinggal, perkantoran, pusat perbelanjaan, taman hiburan dan lain-lain. Sudah selayaknya apabila perusahaan pengembang mendapatkan keuntungan yang besar dari kenaikan harga properti tersebut, dan dengan keuntungan yang diperolehnya maka perusahaan pengembang dapat memperbaiki kinerja keuangannya sehingga dapat menaikkan harga saham.

Ada beberapa fenomena yang muncul akhir-akhir ini pada bisnis property dan real estate dilingkungan global maupun regional yang menarik untuk diamati, antara lain: (1) Tingginya tingkat pertumbuhan industri property dan real estate di Indonesia pasca krisis moneter. Peningkatan ini terutama digerakkan oleh banyaknya pembangunan pusat-pusat perdagangan, hunian mewah serta gedung-gedung perkantoran. (2) Industri property dan real estate dikenal sebagai bisnis yang memiliki siklus yang cepat berubah, persisten dan kompleks. Gambaran fenomena ini tentunya dapat mempengaruhi tingkat return saham dalam perusahaan property dan real estate.

Berinvestasi di pasar modal tidak saja memerlukan pemikiran yanglebih rumit dan informasi yang lebih kompleks, namun juga menghadapiresiko yang relatif besar bila dibanding dengan bentuk-bentuk simpanan pada sistem perbankkan. Oleh karena itu, tidak semua saham dari perusahaan yang memiliki profil yang baik akan memberikan return yang baik pada investor sehingga diperlukan analisis yang lebih baik dan mendalam mengenai perusahaan tersebut. Perusahaan mungkin saja mengalami return yang fluktuatif setiap saat karena berbagai macam faktor baik yang bersifat mikro maupun makro.

Investor yang akan melakukan investasi dengan membeli saham di pasar modal akan menganalisis kondisi perusahaan terlebih dahulu agar investasi yang dilakukannya dapat memberikan keuntungan (return). Memperoleh return (keuntungan) merupakan tujuan utama dari aktivitas perdagangan para investor di pasar modal. Para investor menggunakan berbagai cara untuk memperoleh return yang diharapkan, baik melalui analisis sendiri terhadap perilaku perdagangan saham, maupun dengan memanfaatkan sarana yang diberikan oleh para analisis pasar modal, seperti broker, dealer dan manajer investasi. Pola perilaku perdagangan saham di pasar modal dapat memberi kontribusi bagi pola perilaku harga saham di pasar modal tersebut. Pola perilaku harga saham akan menentukan pola return yang diterima dari saham tersebut (Budi dan Nurhatmini, 2003).

Return saham merupakan hasil yang diperoleh dari kegiatan investasi. Return dibedakan menjadi dua, yaitu return realisasi (return yang terjadi atau dapat juga disebut sebagai return sesungguhnya) dan expected return (return yang diharapkan oleh investor) (Jogiyanto, 2003). Harapan untuk memperoleh return juga terjadi dalam asset financial. Suatu asset financial menunjukkan kesediaan investor menyediakan sejumlah dana pada saat ini untuk memperoleh sebuah aliran dana pada masa yang akan datang sebagai kompensasi atas faktor waktu selama dana ditanamkan dan risiko yang ditanggung. Dengan demikian para investor sedang mempertaruhkan suatu nilai sekarang untuk sebuah nilai yang diharapkan pada masa mendatang.

Investor dalam asset financial juga mengharapkan return yang maksimal. Harapan untuk memperoleh return yang maksimal tersebut diusahakan agar dapat terwujud dengan mengadakan analisis dan upaya tindakantindakan yang berkaitan dengan investasi dalam sahamnya. Oleh karena itu, perlu diketahui faktor-faktor yang mempengaruhi return saham sehingga harapan untuk memperoleh return yang maksimal bisa dicapai. 
Dari data yang diperoleh peneliti dari Bursa Efek Indonesia dari tahun 2007 sampai dengan tahun 2012 pada perusahaan property dan real estate terlihat adanya pergerakan return saham yang fluktuatif dan terjadi kenaikan maupun penurunan return saham yang cukup signifikan, dimana return saham dari tahun 2007 ke tahun 2008 telah terjadi penurunan ratarata sebesar 191,86\%, pada tahun 2009 terjadi kenaikan rata-rata sebesar $48,05 \%$, tahun 2010 return saham terus menunjukkan grafik positif dengan kenaikan rata-rata sebesar 27,96\% dan tahun 2011 return saham menunjukkan kenaikan rata-rata sebesar $11,74 \%$, akan tetapi pada tahun 2012 return saham menunjukkan terjadi penurunan rata-rata sebesar $31,25 \%$ yang disebabkan dengan tingginya inflasi pada saat itu.

\section{Telaah Teori dan Pengembangan Hipotesis}

Teori pensinyalan menjelaskan tentang bagaimana para investor memiliki informasi yang sama tentang prospek perusahaan manajer perusahaan ini disebut informasi asimetris. Namun dalam kenyataannya manajer sering \& memiliki informasi lebih baik dari investor luar. Hal ini disebut informasi asimetris dan ini memiliki dampak penting pada struktur modal yang optimal (Brigham, 2010). Signalling theory juga menjelaskan mengapa perusahaan mempunyai dorongan untuk memberikan informasi laporan keuangan pada pihak internal. Dorongan perusahaan untuk memberikan informasi tersebut adalah karena terdapat asimetris informasi antara perusahaan dan pihak investor karena perusahaan mengetahui lebih banyak mengenai perusahaan dan prospek yang akan datang dibanding pihak luar (investor, kreditor) (Minar Simanungkalit, 2009). Menurut teori sinyal kegiatan perusahaan memberikan informasi kepada investor tentang prospek return masa depan yang substansial. Informasi sebagai sinyal yang diumumkan pihak manajemen kepada publik bahwa perusahaan memiliki prospek bagus dimasa depan (Yeye Susilowati, 2006). Motivasi signalling mendorong manajemen menyajikan laporan laba yang dapat mencerminkan laba sesungguhnya (Sunarto, 2008). Menurut Hapyani P. N. (2009), dalam membangun signaling teory berdasarkan adanya assimetric information antara wellinformed manager dan poorinformed stockholder Teori ini berdasarkan pemikiran bahwa manajer akan mengumumkan kepada investor ketika mendapatkan informasi yang baik, bertujuan menaikkan nilai perusahaan, namun investor tidak akan mempercayai tersebut, karena manajer merupakan interest party. Solusinya perusahaan bernilai tinggi akan berusaha melakukan signalling pada financial policy mereka yang memakan biaya besar sehingga tidak dapat ditiru oleh perusahaan yang memiliki nilai lebih rendah.

Signal adalah proses yang memakan biaya berupa deadweight costing, bertujuan untuk meyakinkan investor tentang nilai perusahaan. Signal yang baik adalah yang tidak dapat ditiru oleh perusahaan lain yang memiliki nilai lebih rendah, karena faktor biaya. Teori ini akan mengungkapkan bahwa investor dapat membedakan antara perusahaan yang memiliki nilai tinggi dengan perusahaan yang memiliki nilai rendah dengan mengobservasi kepemilikan struktur permodalannya serta menandai evaluasi tinggi untuk perusahaan yang hightly levered. Equilibrium stabil karena perusahaan bernilai rendah tidak dapat meniru perusahaan yang lebih tinggi. Kelebihan teori ini adalah kemampuan menjelaskan mengapa terjadi peningkatan harga salam sebagai tanggapan terhadap peningkatan financial leverage. Kelemahan dari model ini adalah ketidakmampuan dalam menjelaskan hubungan kebalikan antara profitabilitas dan leverage. Kelemahan lain adalah tidak dapat menjelaskan mengapa perusahaan yang memiliki potensi pertumbuhan dan nilai intangible asset tinggi harus menggunakan lebih banyak hutang dan pada perusahaan yang mature (tangible asset tinggi) yang tidak menggunakan utang, akan tetapi di dalam teori diperlukan untuk mengurangi efek dari ketidaksimetrisan informasi.

Salah satu jenis informasi yang dikeluarkan oleh perusahaan yang dapat menjadi 
signal bagi pihak di luar perusahaan, terutama bagi pihak investor adalah laporan tahunan. Informasi yang diungkapkan dalam laporan tahunan dapat berupa informasi akuntansi yaitu informasi yang berkaitan dengan laporan keuangan dan informasi non akuntansi yaitu informasi yang tidak berkaitan dengan laporan keuangan. Perusahaan dengan prospek yang cerah lebih memiliki untuk tidak melakukan pendanaan melalui penawaran saham baru, sedangkan perusahaan dengan prospek buruk akan memilih untuk melakukan pendanaan dengan ekuitas pihak luar (Brigham dan Houston, 2010).

Menurut Jogiyanto (2009), faktor fundamental adalah faktor yang berhubungan dengan kondisi perusahaan, yang meliputi kondisi manajemen, organisasi, dan keuangan perusahaan yang tercermin dalam kinerja perusahaan. Analisis rasio merupakan alat untuk memberi pemahaman awal terhadap kondisi yang terjadi dan membantu untuk mengidentifikasi area yang memerlukan investigasi lebih lanjut diinterpretasi.Analisis rasio dapat dikelompokkan ke dalam 5 macam kategori: Rasio Likuiditas (Liquidity ratio), Rasio Solvabilitas (Solvency ratio), Rasio Aktivitas (activity ratio), Rasio Profitabilitas (profitability ratio) atau rasio rentabilitas, Rasio Paw (market ratio). Menurut Bodie (2005) Analisis rasio pasar adalah rasio yang mengukur harga pasar relatif terhadap nilai buku berdasarkan pada sudut pandang investor. Ada beberapa macam rasio pasar. Price Earning Ratio, Dividend yield, Dividen pay out, Earnings yield, Price to book value. Dengan demikian dapat dipahami bahwa faktor fundametal adalah faktor yang berhubungan dengan kondisi internal perusahaan yang dapat mempengaruhi suatu kondisi dalam perusahaan tersebut. Faktor ini sering disebut dengan kinerja perusahaan, baik kinerja keuangan maupun kinerja non keuangan. Kinerja keuangan biasa diwujudkan dengan rasio rasio keuangan yang diperoleh dari hasil analisis laporan keuangan yang diekspos kepada publik.

Hanafi \& Abdul Halim (2009) mengkategorikan analisa rasio dalam lima kelompok, yaitu: (1) rasio likuditas; (2) rasio aktivitas; (3) rasio profitabilitas; (4) rasio solvabilitas; dan (5) rasio pasar. Analisis kinerja keuangan sendiri sering digunakan untuk memprediksi dari perkiraan return saham ke depan. Pada penelitian ini, faktor kinerja keuangan yang digunakan untuk melakukan prediksi tersebut berupa rasio keuangan yang terdiri atas Asset Growth (AG), Price Earning Ratio (PER), Return on Equity (ROE), dan Debt to Equity Ratio (DER).

Asset growth menunjukkan pertumbuhan asset di mana asset merupakan aktiva yang digunakan untuk aktiva operasional perusahaan. Asset growth yang tinggi akan berimplikasi pada tingkat resiko yang tinggi pula, hal ini dapat dijelaskan bahwa pemakaian aktiva yang tinggi akan memberikan tanggungan terhadap pengembalian investasi yang tinggi dan merupakan resiko yang yang tinggi apabila tidak dapat menutup pengembalian investasi tersebut. (Utami, 2001). Hartono (2009) dalam penelitiannya menyimpulkan secara empiris bahwa Income Growth Asset Growth Sales Growth dan Debt to Equity Ratio (DER) mempunyai signifikansi terhadap return saham secara bersamasama meskipun hanya mampu menjelaskan 5,9\% variasi pada return saham. Pipit (2012) dalam penelitiannya menyimpulkan secara parsial hanya variabel Return on Equity saja yang mempunyai pengaruh secara signifikan terhadap harga saham sementara Return on Asset, Rentabilitas Ekonomi, dan Pertumbuhan Asset tidak mempunyai pengaruh terhadap harga saham. Secara simultan, empat rasio keuntungan Return on Equity, Return on Asset, Rentabilitas Ekonomi, dan Pertumbuhan Asset mempunyai pengaruh yang signifikan terhadap harga saham. Asset Growth adalah ratarata pertumbuhan kekayaan perusahaan. Bila kekayaan awal suatu perusahaan adalah tetap jumlahnya, maka pada tingkat pertumbuhan aktiva yang tinggi besarnya kekayaan akhir perusahaan tersebut semakin besar. Demikian pula sebaliknya. Pada tingkat pertumbuhan aktiva yang tinggi, bila besarnya kekayaan akhir tinggi berarti kekayaan awalnya rendah.

Price Earning Ratio (PER) adalah cara mengukur seberapa besar investor menilai laba 
yang dihasilkan perusahaan. Price Earning Ratio (PER) penting karena jumlah laba yang dihasilkan perusahaan sebetulnya akan menentukan jumlah dividen yang akan bisa dibayarkan di masa yang akan datang. Jika labanya naik maka dividen juga akan naik. Secara umum saham dengan Price Earning Ratio (PER) yang rendah sering biasa terjadi jika ada penurunan laba bersih yang menjadi elemen pembagi dalam kalkulasi Price Earning Ratio (PER). Saham dengan Price Earning Ratio (PER) yang tinggi menunjukkan penerbit saham tersebut tumbuh dengan pesat. Zaenal Arifin (2005) mendefinisikan price earning ratio sebagai cerminan dari seberapa besar uang yang berani dibayar oleh investor untuk setiap lembar saham. Dengan demikian, apabila $\mathrm{P} / \mathrm{E}$ ratio menunjukkan angka yang tinggi maka investor bersediaan membayar lebih mahal untuk setiap lembar saham.

Rasio ini menggambarkan ketersediaan investasi membayar suatu jumlah tertentu untuk setiap perolehan laba perusahaan. Price earning ratio dapat dihitung dengan prbandingan anatara harga pasar per lembar saham dan laba bersih per lembar saham. Semakin meningkatnya Price Earning Ratio (PER) mencerminkan kinerja perusahaan. Meningkatnya kinerja perusahaan memberikan respon positif bagi investor, yang mengakibatkan meningkatnya harga saham. Semakin menigkatnya harga saham dengan sendirinya meningkatnya abnormal return saham. Hal ini berarti bahwa jika Price Earning Ratio (PER) meningkat, return juga akan meningkat.

Return on Equity adalah rasio untuk mengukur seberapa efektif perusahaan memanfaatkan kontribusi pemilik dan atau seberapa efektifnya perusahaan memanfaatkan sumber-sumber lain untuk kepentingan pemilik. Rumusuntuk Returnon Equity(ROE) yaitu dengan membagi Net Income After Tax (NIAT) dengan share holder equity (Brigham dan Houston dalam Ali Akbar Yulianto(2004)). Dari sudut pandang investor Return on Equity (ROE) merupakan salah satu indikator penting untuk menilai prospek perusahaan di masa yang akan datang. Dengan mengetahui tingkat Return on Equity (ROE), investor dapat melihat pertumbuhan profitabilitas perusahaan. Indikator Return on Equity (ROE) sangat penting diperhatikan untuk mengetahui investasi yang akan dilakukan investor di suatu perusahaan mampu memberikan return yang sesuai dengan tingkat yang diharapkan, Return on Equity (ROE) akan berubah jika earning after tax atau equity berubah.

Dalam menentukan pilihannya, investor biasanya akan mempertimbangkan perusahaan yang mampu memberikan kontribusi Return on Equity (ROE) yang lebih besar. Bagi investor semakin tinggi Return on Equity (ROE) menunjukkan risiko investasi semakin kecil. Indikator Return on Equity (ROE) yang meningkat sangat penting diperhatikan untuk mengetahui investasi yang akan dilakukan investor. Dengan Return on Equity (ROE) yang tinggi suatu perusahaan mampu memberikan return sesuai dengan tingkat yang diharapkan; meningkatnya Return on Equity (ROE) akan meningkatkan return saham.

Tingkatkewajiban yang tinggi menjadikan pihak manajemen perusahaan menjadi lebih sulit dalam membuat prediksi jalannya perusahaan ke depan. Financial leverage dipertimbangkan sebagai variabel keuangan dalam penelitian ini karena secara teoritis financial leverage menunjukkan risiko suatu perusahaan sehingga berdampak pada ketidakpastian suatu harga saham Financial leverage yang digunakan dalam penelitian ini adalah Debt to Equity Ratio (DER). Finacial leverage menujukkan kemampuan perusahaan dalam membayar hutang dengan equity yang dimilikinya. Tingginya finacial leverage meunjukkan risiko finacial atau risiko kegagalan perusahaan untuk mengembalikan pinjaman akan semakin tinggi, dan sebaliknya.

Debt to Equity ratio menunjukkan seberapa besar aktiva perusahaan dibiayai oleh hutang atau seberapa besar hutang perusahaan berpengaruh terhadap pengelolaan akuitas. Debt to Equity Ratio diperoleh dengan total hutang dibagi dengan total ekuitas, setiap rupiah modal dijadikan jaminan untuk keseluruhan utang. (Van Horme dalam Heru sutojo). Debt to Equity Ratio (DER) yang semakin besar akan mengakibatkan risiko financial peusahaan 
semakin tinggi. Dengan penggunaan hutang yang semakin besar akan mengakibatkan semakin tinggi risiko untuk tidak mampu membayar hutang. Investor biasanya menghindari risiko, maka semakin tinggi Debt to Equity Ratio (DER) akan mengakibatkan saham perusahaan tersebut dihindari investor, sehingga harga saham semakin rendah. dengan meningkatnya Debt to Equity Ratio (DER) berarti akan meningkatkan risiko berinvestasi, dengan demikian investor merespon negatif terhadap kinerja perusahaan. Rendahnya kinerja perusahaaan berakibat harga saham akan mengalami penurunan. Menurunnya harga saham akan mengakibatkan return yang semakin menurun

Faktor-faktor yang mempengaruhi harga saham yang berasal dari luar perusahaan yang menerbitkan saham. Faktor makro ekonomi ini ada yang terjadinya sepanjang waktu suku bunga bank, nilai kurs valuta asing, inflasi, tapi juga ada yang terjadinya tidak menentu seperti kebijakan ekonomi, kondisi ekonomi, statment pemerintah, isuisu politik, dan informasiinformasi yang menyesatkan. Dalam penelitian ini, faktor makro ekonomi yang digunakan untuk melakukan prediksi tersebut berupa inflasi.

Inflasi adalah ukuran ekonomi yang memberikan gambaran tentang meningkatnya harga ratarata barang dan jasa yang diproduksi pada suatu sistem perekonomian (Suseno, dalam Sugeng, 2004). Inflasi merupakan kecenderungan terjadinya peningkatan harga produk secara keseluruhan(Tandefilin, 2010). Samuelson (2001) memberikan definisi bahwa inflasi sebagai suatu keadaan dimana terjadi kenaikan tingkat harga umum, baik barang-barang, jasajasa maupun faktorfaktor produksi. Dari definisi tersebut mengindikasikan keadaan melemahnya daya beli yang diikuti dengan semakin merosotnya nilai riil (intrinsik) mata uang suatu negara. Inflasi menurut Rimsky K. Judisseno (2002) adalah salah satu peristiwa moneter yang menunjukkan suatu kecenderungan akan naiknya harga barangbarang secara umum, yang berarti terjadinya penurunan nilai uang. Sedangkan Sadono Sukimo (2006) mengemukakan definisi inflasi yaitu inflasi adalah suatu proses kenaikan hargaharga yang berlaku dalam suatu perekonomian.

Tingkat inflasi yang tinggi biasanya dikaitkan dengan kondisi ekonomi yang terlalu panas (overheated). Artinya, kondisi ekonomi mengalami permintaan atas produk yang melebihi kapasitas penawaran paroduknya, sehingga hargaharga cenderung mengalami kenaikan. Inflasi yang terlalu tinggi juga akan menyebabkan penurunan daya beli uang (purchasing power of money). Di samping itu, inflasi yang tinggi juga bisa mengurangi tingkat pendapatan riil yang diperoleh investor dari investasinya. Sebaliknya jika tingkat inflasi suatu negara mengalami penurunan, maka hal ini akan merupakan sinyal yang positif bagi investor seiring dengan turunnya resiko daya beli uang dan resiko penurunan pendapatan riil (Tandelilin, 2010).

\section{Metode}

Populasi dalam penelitian ini adalah perusahaan property dan real estate yang tercatat di Bursa Efek Indonesia (BEI), sesuai dengan publikasi ICMD 2012 untuk kelompok usaha property dan real estate yang terdiri dari empat puluh sembilan (49) perusahaan untuk periode tahun 2007 sampai dengan 2012. Alasan digunakannya data mulai dari tahun 2007 adalah karena adanya pergerakan fluktuatif pada return saham, dan data yang digunakan adalah laporan keuangan enam tahun yang terakhir. Dari empat puluh sembilan (49) perusahaan tersebut terdapat delapan belas (18) perusahaan yang tidak menerbitkan data secara berturutturut, mka dipilih sebanyak tiga puluh satu (31) perusahaan yang ada dan data yang cukup untuk keperluan penelitian ini. Dan dari tiga puluh satu (31) perusahaan yang ada tercatat enam (6) perusahaan dengan data outlier sehingga tersisa dua puluh lima (25) perusahaan saja. Sedangkan Kriteria yang digunakan untuk penentuan sampel dalam penelitian ini adalah:

1. Perusahaan property dan real estate yang tercatat di Bursa Efek Indonesia selama tahun 20072012.

2. Data laporan keuangan tersedia untuk periode tahun 20072012. 
3. Perusahaan mempublikasikan laporan keuangan auditan dengan menggunakan tahun buku yang berakhir pada tanggal 31 Desember. Kriteria ini diambil guna memudahkan peneliti sehingga tidak perlu melakukan konversi ke dalam 31 Desember apabila perusahaan menerbitkan laporan keuangan bukan per 31 Desember.

Data yang digunakan dalam penelitian ini merupakan data sekunder dimana metode pengumpulan data yang digunakan adalah dengan strategi langsung dan dengan mencatat atau mendokumentasikan data, teknik ini digunakan untuk data lapangan dan pengumpulan data dan basis data yang pada laporan keuangan pemahaman dan yang dipublikasikan oleh Indonesian Capital Market Directory (ICMD) ataupun Bursa Efek Indonesia (BEI).

Analisis data penelitian ini adalah analisis kuantitatif. Teknik analisis statistik dalam penelitian ini menggunakan regresi linier berganda (multiple linear regression). Sebelum melakukan analisis regresi linier berganda terlebih dahulu dilakukan uji statistik deskripsi dan uji asumsi klasik. Uji statistik deskriptif digunakan untuk mendeskripsikan secara ringkas variabel-variabel dalam penelitian ini. Analisis deskripsi dilakukan untuk mengetahui gambaran atau deskripsi suatu data yang akan dianalisis. Ghozali (2012) menyebutkan bahwa statistik deskriptif memberikan gambaran atau deskripsi suatu data yang dilihat dari nilai rata-rata (mean), standar deviasi, varian, maksimum, minimum, sum, range, kurtosis dan skewness (kemenangan distribusi). Statistik deskriptif menyaikan ukuranukuran numerik yang sangat penting bagi data sampel. Ukuran numerik ini merupakan bentuk penyederhanaan data ke dalam bentuk yang lebih ringkas dan sederhana yang pada akhirnya mengarah pada suatu penjelasan dan penafsiran.

Penelitian ini menggunakan analisis regresi berganda. Analisis ini digunakan untuk mengukur kekuatan dua variabel atau lebih dan juga menunjukkan arah hubungan antara variabel terikat dengan variabel independen. Adapun rumus dari regresi linier berganda (multiple linier regesion) adalah sebagai berikut :

$$
\begin{aligned}
\mathrm{Y}= & \mathrm{a}+\mathrm{bl} \mathrm{X} 1+\mathrm{b} 2 \mathrm{X} 2+\mathrm{b} 3 \mathrm{X3}+\mathrm{b} 4 \mathrm{X} 4+\mathrm{b} 5 \\
& \mathrm{X} 5+\mathrm{b} 6 \mathrm{X6}+\mathrm{e} .
\end{aligned}
$$

Dimana :

$\mathrm{Y}=$ Return saham

$\mathrm{X}_{1}=$ Asset growth

$\mathrm{X}_{2}=$ Return On Equity

$\mathrm{X}_{3}=$ Price Earning Ratio

$\mathrm{X}_{4}=$ Debt to Equity Ratio

$\mathrm{X}_{5}=$ Inflasi

$\mathrm{a} \quad=$ Konstanta

$\mathrm{b}_{1}, \mathrm{~b}_{2}=$ Koefisien regresi dari setiap variabel in dependen

e $\quad=$ Faktor kesalahan

Untuk menguji signifikan model, digunakan pendekatan ANOVA (F-Test) dan untuk menguji signifikasi koefisien regresi setiap variabel independen digunakan t-test.

\section{Hasil Penelitian dan Pembahasan}

Berdasarkan jumlah sampel yang memenuhi syarat untuk digunakan dalam penelitian, dapat diketahui statistik deskriptif variabel yang berfungsi untuk mengetahui karakteristik sampel yang meliputi jumlah sampel, rata-rata sampel (mean). Berdasarkan hasil uji statistic deskriptif bahwa selama periode 2007 - 2012 secara umum harga saham mengalami kenaikan. Standar deviasi return saham sebesar 0,91646 atau $9,2 \%$, standar deviasi return saham melebihi rata-rata return sahamnya, dengan besarnya simpangan data menunjukkan tingginya fluktuasi variabel return saham selama periode pangamatan. Berdasarkan nilai rata-rata dapat disimpulkan bahwa kemampuan perusahaan menghasilkan laba bagi para pemegang saham, yang dapat dilihat dari kemampuan modal sendiri dalam menghasilkan laba sebesar 5,3074 kali. Berdasarkan nilai rata-rata dapat disimpulkan bahwa kemampuan perusahaan dalam memenuhi kewajibannya dengan equity yang dimilikinya sebesar 0,8682 kali. Berdasarkan nilai rata-rata dapat disimpulkan bahwa apresiasi pasar terhadap kemampuan perusahaan menghasilkan laba sebesar 383,68 \% atau pasar menghargai 3,8368 kali atas kemampuan perusahaan menghasilkan laba. Berdasarkan nilai rata-rata dapat 
disimpulkan bahwa kemampuan aset perusahaan yang digunakan untuk aktiva perusahaan dalam mempertahankan posisi ekonominya sebesar 2,6581. Variabel inflasi merupakan ukuran ekonomi yang memberikan gambaran tntang mnngkatnya harga rata-rata barang dan jasa yang diproduksi pada suatu sistem perekonomian memiliki nilai minimum (terkecil) 2,71 dan maksimal (terbesar) 12,14, mean (nilai rata-rata) 7,0139 dan standart deviation (simpangan baku) variabel ini adalah 2,74897.

Uji asumsi klasik dilakukan untuk memastikan bahwa model yang diuji dengan uji linier berganda memenuhi syarat best, linier, unbiased, dan estimated.Pengujianyangdilakukan mencakup uji normalitas, multikolinearitas, heteroskedastisitas, dan autokorelasi. Pengujian normalitas data dengan hanya melihat gafik dapat menyesatkan kalau tidak melihat secara seksama, sehingga kita perlu melakukan uji normalitas data dengan menggunakan statistik agar lebih meyakinkan. Untuk dapat memastikan apakah data yang digunakan sepanjang garis diagonal berdistribusi normal, maka dilakukan uji kolmogorov-Smirnov (1 sample KS) dengan melihat data residualnya apakah berdistribusi normal atau tidak. Jika nilai signifikansinya lebih besar dari 0,05 maka data tersebut terdistribusi normal. Jika nilai signifikansinya lebih kecil dari
0,05 maka distribusi data adalah tidak normal. Hasil uji kolmogorov-Smirnov pada penelitian ini menunjukkan Asymp.Sig.(2-tailed) =0,615. Dengan demikian, data yang digunakan pada penelitian ini berdistribusi normal karena Asymp. Sig.(2-tailed) lebih besar (>) dari 0,05 dan dapat digunakan untuk melakukan Uji-t dan Uji-F karena $0,615>0,05$ ( $\mathrm{H}_{\circ}$ di terima).

Menurut Ghozali (2012), uji ini bertujuan menguji apakah pada model regresi ditemukan adanya korelasi antar variabel independen. Pada model regresi yang baik antar variabel independen sahammya tidak terjadi korelasi. Untuk mendeteksi ada tidaknya multikolinieritas dalam model regresi dilakukan dengan melihat nilai tolerance dan nilai Variance Factor (VIF) yang dapat dilihat dari output SPSS. Sebagai dasar acuannya dapat disimpulkan:

1) Jika nilai tolerance $>10$ persen dan nilai VIF $<10$, maka dapat disimpulkan bahwa tidak ada multikolinieritas antar variabel independen dalam model regresi.

2) Jika nilai tolerance $<10$ persen dan nilai VIF $>10$, maka dapat disimpulkan bahwa ada multikolinieritas antar variabel independen dalam model regresi.

Hasil pengujian terhadap multikolinearitas pada penelitian ini dapat dilihat nilai $\mathrm{VIF}<10$ yaitu 1,$151 ; 1,041 ; 1,060 ; 1,043 ; 1,091$. Pada

Tabel 1. Uji White Heterokedasticity

\begin{tabular}{|c|c|c|c|c|}
\hline Variable & Coefficient & Std. Error & t-Statistic & Prob. \\
\hline $\mathrm{C}$ & -0.591144 & 0.222636 & -2.655204 & 0.0088 \\
\hline ROE & 0.026832 & 0.006683 & 4.014856 & 0.0001 \\
\hline DER & -0.002462 & 0.067700 & -0.036373 & 0.9710 \\
\hline PER & 0.061229 & 0.032983 & 1.856374 & 0.0654 \\
\hline $\mathrm{AG}$ & -0.035824 & 0.025426 & -1.408930 & 0.1610 \\
\hline INFLASI & 0.049669 & 0.022840 & 2.174644 & 0.0313 \\
\hline R-squared & 0.230788 & \multicolumn{2}{|c|}{ Mean dependent var } & 0.037200 \\
\hline Adjusted R-squared & 0.204079 & \multicolumn{2}{|c|}{ S.D. dependent var } & 0.916463 \\
\hline S.E. of regression & 0.817617 & \multicolumn{2}{|c|}{ Akaike info criterion } & 2.474333 \\
\hline Sum squared resid & 96.26367 & \multicolumn{2}{|c|}{ Schwarz criterion } & 2.594758 \\
\hline Log likelihood & -179.5750 & \multicolumn{2}{|c|}{ Hannan-Quinn criter. } & 2.523258 \\
\hline F-statistic & 8.640914 & \multicolumn{2}{|c|}{ Durbin-Watson stat } & 1.705433 \\
\hline Prob(F-statistic) & 0.000000 & & & \\
\hline
\end{tabular}


umumnyaterjadinyamultikolinieritasapabilanilai VIF $>10$. berarti dapat disimpulkan bahwa dalam penelitian ini tidak terjadi multikolinieritas.

Uji heteroskedastisitas bertujuan menguji apakah dalam model regresi terjadi variance dan residual satu pengamatan kepengamatan lain. Aka variance dari residual satu pengamatan kepengamatan lain tetap, maka disebut homokedastisitas dan jika berbeda disebut heterokedastisitas. Model regresi yang baik adalah yang Homokedastisitas atau tidak terjadi heterokedastisitas. Uji white dilakukan untuk menguji heteroskedastisitas dengan meregresikan residual kuadrat sebagai variabel dependen dengan variabel dependen ditambah dengan kuadrat variabel independen, kemudian ditambahkan lagi dengan perkalian dua variabel independen, pada Tabel 1 hasil output menunjukkan nilai $O b s^{*} R$-squared dibawah 0,05 , sedangkan nilai probabilitas (chi-square) lebih besar daripada $\alpha=0,05$, dengan demikian kita dapat menerima hipotesis nol bahwa data tidak mengandung masalah heteroskedastisitas.

Uji autokorelasi bertujuan untuk menguji apakah dalam suatu model regresi linier ada korelasi antara kesalahan pengganggu (residual) pada periode $\mathrm{t}$ dengan kesalahan pada periode t1 (sebelumnya). Jika terjadi korelasi, maka dinamakan ada problem auto korelasi (Ghozali, 2012).
DW test sebagai bagian dari statistik nonparametrik dapat digunakan untuk menguji korelasi tingkat satu dan mensyaratkan adanya intercept dalam model regresi dan tidak ada variabel lag diantara variabel independen. Untuk menguji ada tidaknya gejala autokorelasi maka dapat dideteksi dengan uji DurbinWaston test ( $D W$ test). Pengambilan keputusan ada tidaknya autokorelasi pada Tabel 2.

Tabel 2. Durbin Watson d test Pengambilan Keputusan

\begin{tabular}{ll}
\hline \multicolumn{1}{c}{ NILAI DW } & \multicolumn{1}{c}{ HASIL } \\
\hline $4-\mathrm{dI}<\mathrm{DW}<4$ & Tolak Ho, korelasi serial negatif \\
4-du $<\mathrm{DW}<4$-dl & Hasil tidak dapat ditentukan \\
$2<\mathrm{DW}<4$-du & Terima Ho, tidak ada korelasi \\
& serial \\
$\mathrm{du}<\mathrm{DW}<2$ & Terima Ho, tidak ada korelasi \\
& serial \\
$\mathrm{dl}<\mathrm{DW}<\mathrm{du}$ & Hasil tidak dapat ditentukan \\
$0<\mathrm{DW}<\mathrm{dl}$ & Tolak Ho, korelasi serial positif \\
\hline
\end{tabular}

\section{Hasil Uji Hipotesis}

Pengujian hipotesis mencakup uji model penelitian dengan menggunakan uji $\mathrm{F}$ dan Adjusted R-Squared serta Uji pengaruh masingmasing variable terhadap dependen variable. Rangkuman hasil pengujian tersebut dapat dilihat pada Tabel 3.

Tabel 3. Hasil Pengujian Hipotesis

\begin{tabular}{lcccc}
\hline \multicolumn{1}{c}{ Keterangan } & B & Std. Error & t-hitung & Sig. \\
\hline ROE & 0.027 & 0.006 & 4.243 & 0.000 \\
DER & 0.002 & 0.069 & -0.036 & 0.972 \\
PER & 0.061 & 0.023 & 2.656 & 0.009 \\
ASSET GROWTH & 0.036 & 0.031 & -1.159 & 0.249 \\
INFLASI & 0.050 & 0.149 & 1.952 & 0.053 \\
Constant & -0.591 & 0.228 & 1.952 & 0.053 \\
R-Square & 0.654 & & & \\
Adjusted R-Square & 0.640 & & & \\
F-hitung & 8.641 & & & \\
Sig. F & 0.000 & & & \\
\hline
\end{tabular}


Uji statistik F pada dasarnya menunjukkan apakah semua variabel independen yang dimasukkan dalam model mempunyai pengaruh secara bersamasama terhadap variabel terikat (Ghozali, 2012). Pada tabel anova dapat diketahui dengan nilai signifikan dalam penelitian ini adalah 0,000 yang berarti angka ini berada dibawah 0,05. Diketahui bahwa $\mathrm{F}_{\text {tabel }}$ adalah sebesar 2,28 sedangkan $\mathrm{F}_{\text {hitung }}$ adalah sebesar 8,641 yang berarti $\mathrm{F}_{\text {hitung }}>\mathrm{F}_{\text {tabel }}(8,641>2,28)$. Kesimpulan yang dapat diambil adalah $\mathrm{H}_{\circ}$ ditolak sehingga variabel return on equity (ROE), price earning ratio (PER), debt to equity ratio (DER), asset growth $(A G)$, dan inflasi secara simultan (bersama-sama) berpengaruh sinifikan terhadap return saham.

Besarnya kontribusi antara variabel return on equity (ROE), price earning ratio (PER), debt to equity ratio (DER), asset growth (AG), dan inflasi terhadap return saham pada perusahaan property dan real estate yang terdaftar di bursa efek indonesia dapat diketahui dari nilai koefisien determinasi ganda atau $\mathrm{R}^{2}$. Dalam penelitian ini penulis menggunakan pengukuran dengan adjusted $\mathrm{R}^{2}$. Koefisien Determinasi adalah bagian dari variasi total dalam variabel dependen yang dijelaskan oleh variasi dalam variabel indepen, disebut juga dengan RSquared dan dinotasikan dengan $\mathrm{R}^{2}$. Koefisien deteterminasi $\left(\mathrm{R}^{2}\right)$ digunakan untuk mengukur seberapa jauh kemampuan model dalam menerangkan variasi variabel dependen.

Nilai koefisien korelasi antara variabel ROE $\left(X_{1}\right)$, DER $\left(X_{2}\right)$, PER $\left(X_{3}\right)$ AG $\left(X_{4}\right)$ dan INFLASI $\left(\mathrm{X}_{5}\right)$ terhadap rs $(\mathrm{Y})$ adalah 0,780 , dan besarnya koefisien determinasi (Adjusted $R^{2}$ ) diperoleh sebesar 0,640 , sedangkan dari tabel dapat dibaca pula bahwa nilai $\mathrm{R}$ square $\left(\mathrm{R}^{2}\right)$ adalah 0,654 , artinya $65 \%$ variasi yang terjadi terhadap tinggi atau rendahnya return saham disebabkan variasi ROE, DER, PER, AG dan INFLASI sedangkan sisanya (35\%) dipengaruhi variabel lain diterangkan Adjusted $R$ square merupakan nilai $\mathrm{R}^{2}$ yang disesuaikan sehingga gambarannya lebih mendekati mutu penjajakan model dalam populasi. Std. Error of the Estimation merupakan kesalahan standar dari penaksiran dan bernilai
0,40670

Uji t dilakukan untuk menguji koefisien regresi secara parsial dari variabel independennya. Uji statistik $\mathrm{t}$ pada dasarnya menunjukkan seberapa jauh pengaruh satu variabel independen secara individual dalam menerangkan variasi variabel dependen (Ghozali, 2012). Tingkat signifikansi yang digunakan sebesar 5\%, dengan derajat kebebasan $\mathrm{df}=(\mathrm{k} 1)$, dimana $(\mathrm{n})$ adalah jumlah observasi dan (k) adalah jumlah variabel. Uji ini dilakukan dengan membandingkan $\mathrm{t}$ hitung dengan $t$ tabel dengan ketentuan Ho diterima jika t hitung $<\mathrm{t}$ tabel untuk a $=5 \%$, untuk mengetahui pengaruh masing-masing variabel bebas terhadap variabel terikat yaitu antara variabel return on equity (ROE), debt to equity ratio (DER), price earning ratio (PER), asset growth $(A G)$, dan inflasi terhadap return saham dalam penelitian ini dilakukan pengujian terhadap koefisien regresi yaitu dengan uji t. Dapat diketahui nilai probabilitas value masingmasing variabel independen terhadap variabel dependen. Jika probabilitas value $>0,05$ maka

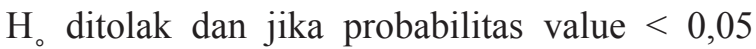
maka Ha diterima. Atau Jika $t_{\text {hitung }}>t_{\text {tabel }}$ yaitu ta (k-1,n-k), maka H0 ditolak yang berarti variabel independen (ROE, PER, DER, $A G$, dan Inflasi) secara individu (parsial berpengaruh terhadap variabel dependen (RS).

Variabel Return on equity (ROE) berpengaruh positif dan signifikan terhadap return saham. Hal ini dapat terlihat dari nilai signifikan 0,000 dibawah (lebih kecil) dari 0,05 . Variabel Debt to equity ratio (DER) berpengaruh negatif dan tidak signifikan terhadap return saham. Hal ini terlihat dari nilai signifikan 0.972 diatas (lebih besar) dari 0.05. Variabel Price earning ratio (PER) berpengaruh positif dan signifikan terhadap return saham. Hal ini terlihat dari nilai signifikan 0.009 dibawah (lebih kecil) dari 0.05. Variabel aseets growth $(A G)$ berpengaruh negatif dan tidak signifikan terhadap return saham. Hal ini terlihat dari nilai signifikan 0.249 diatas (lebih besar) dari 0.05 . Variabel inflasi berpengaruh positif dan signifikan terhadap return saham. 


\section{Pembahasan}

Hasil uji berdasarkan hasil analisis dengan menggunakan SPSS 17 maka dapat diperoleh hasil bahwa penelitian ini bebas dari uji asumsi klasik, dan dilihat dari uji f semua variabel independen berpengaruh secara simultan terhadap variabel dependen, hasil dari uji t secara parsial variabel Variabel Return on equity (ROE) berpengaruh positif dan signifikan terhadap return saham, variabel Debt to equity ratio (DER) berpengaruh negatif dan tidak signifikan terhadap return saham., variabel Price earning ratio (PER) berpengaruh positif dan signifikan terhadap return saham. Variabel inflasi berpengaruh positif dan signifikan terhadap return saham.

Hipotesis pertama menyatakan bahwa variabel return on equity (ROE) secara parsial berpengaruh positif dan signifikan terhadap return saham. Hal ini menunjukkan bahwa besarnya return on equity (ROE) pada perusahaan property dan real estate berpengaruh signifikan terhadap return saham, dan mengindikasikan bahwa investor memandang return on equity (ROE) memiliki peranan dalam melakukan/ membuat keputusan investasi. Hasil penelitian ini mendukung penelitian Sunarto (2001), menemukan bahwan ROA, ROE, Leverage berpengaruh sinifikan terhadap return saham; ROA dan ROE berpengaruh paling konsisten terhadap return saham, sedang leverage tidak konsisten berpengaruh terhadap return saham. Penelitian serupa juga dilakukan oleh nainggolan (2004), menemukan bahwa EPS, DER, PER, ROI dan ROE berpengaruh terhadap harga saham sektor properti. Penelitian ini berbeda dengan penelitian yang dilakukan noersasongko dan nila wulandari, mereka menemukan secara parsial EVA dan ROA, ROE, Return on Sale, Basic Earning Power tidak berpengaruh terhadap harga saham.

Hipotesis kedua menyatakan bahwa variabel debt to equity ratio (DER), secara parsial berpengaruh negatif dan tidak signifikan terhadap return saham. Hal ini menunjukkan bahwa besarnya debt to equity ratio (DER) pada perusahaan property dan real estate berpengaruh tidak signifikan terhadap return saham, dan mengindikasikan bahwa investor memandang debt to equity ratio (DER) tidak memiliki peranan dalam melakukan/membuat keputusan investasi. Hasil penelitian ini medukung penelitian Abidin J (2009), menemukan bahwa ROA, ROE, PER dan DER berpengaruh yang rendah terhadap harga saham, sedangkan EPS, BV, ROI, OPM dan beta secara simultan berepngaruh terhadap harga saham. Penelitian ini berbeda dengan penelitian yang dilakukan Nainggolan (2004), menemukan bahwa EPS, DER,PER,ROI dan ROE berpengaruh terhadap harga saham sektor properti.

Hipotesis ketiga menyatakan bahwa variabel price earning ratio (PER) secara parsial berpengaruh positif dan signifikan terhadap return saham. Hal ini menunjukkan bahwa besarnya price earning ratio (PER) pada perusahaan property dan real estate berpengaruh signifikan terhadap return saham, dan mengindikasikan bahwa investor memandang price earning ratio (PER) memiliki peranan dalam melakukan/ membuat keputusan investasi. Hasil penelitian ini medukung penelitian Aydogan dan Gursoy (2002) yang menyatakan bahwa rasio PER dan PBV memiliki kemampuan signifikan dalam menjelaskan ekspekted return saham sepanjang waktu di pasar modal negara berkembang. Hasil penelitian ini juga senada dengan penelitian Nainggolan (2004), menemukan bahwaEPS, DER,PER,ROI dan ROE berpengaruh terhadap harga saham sektor properti. Penelitian ini berbeda dengan penelitian yang dilakukan Abidin J (2009), menemukan bahwa ROA, ROE, PER dan DER berpengaruh yang rendah terhadap harga saham, sedangkan EPS, BV, ROI, OPM dan beta secara simultan berpengaruh terhadap harga saham.

Hipotesis keempat menyatakan bahwa variabel asset growth $(A G)$ berpengaruh positif dan tidak signifikan terhadap return saham. Hal ini menunjukkan bahwa besarnya asset growth $(A G)$ pada perusahaan property dan real estate berpengaruh tidak signifikan terhadap return saham, dan mengindikasikan bahwa investor memandang asset growth $(A G)$ tidak memiliki 
peranan dalam melakukan/membuat keputusan investasi. Hasil penelitian ini sejalan dengan penelitian Irianto Warsito (2003) menemukan bahwa pengujian secara simultan dan parsial pengaruh pertumbuhan aktiva, rasio prifitabilitas dan beta akuntansi terhadap beta saham. Hasil penelitian ini berbeda dengan wiwik Utami (2006) yang menyimpulkan bahwa faktor fundamental perusahaan yang terdiri dari leverage ratio, deviden payout ratio, debt to equity ratio, asset growth, operating ratio, sales growth berpengaruh secara signifikan

Hipotesis kelima menyatakan bahwa variabel inflasi secara parsial berpengaruh positif dan signifikan terhadap return saham. Hal ini menunjukkan bahwa besarnya inflasi pada perusahaan property dan real estate berpengaruh signifikan terhadap return saham, dan mengindikasikan bahwa investor memandang inflasi memiliki peranan dalam melakukan/ membuat keputusan investasi. Hasil penelitian ini sejalan dengan dengan penelitian yang dilakukan yang dilakukan oleh tarazi dan gallato (2012) serta sari dan soytas (2005) yang menyatakan bahwa terdapat hubungan yang signifikan antara inflasi dan return saham.

\section{Kesimpulan, Keterbatasan, dan Implikasi Hasil Penelitian}

Variabel return on equity (ROE) secara parsial berpengaruh positif dan signifikan terhadap return saham. Hal ini menunjukkan bahwa besarnya return on equity (ROE) pada perusahaan property dan real estate berpengaruh signifikan terhadap return saham, dan mengindikasikan bahwa investor memandang return on equity (ROE) memiliki peranan dalam melakukan/membuat keputusan investasi. Penelitian ini didukung oleh Sunarto (2001) dan oleh nainggolan (2004)

1. Variabel debt to equity ratio (DER), secara parsial berpengaruh negatif dan tidak signifikan terhadap return saham. Hal ini menunjukkan bahwa besarnya debt to equity ratio (DER) pada perusahaan property dan real estate berpengaruh tidak signifikan terhadap return saham, dan mengindikasikan bahwa investor memandang debt to equity ratio (DER) tidak memiliki peranan dalam melakukan/membuat keputusan investasi. Penelitian ini medukung penelitian Abidin J (2009), dan penelitian Nainggolan (2004).

2. Variabel price earning ratio (PER) secara parsial berpengaruh positif dan signifikan terhadap return saham. Hal ini menunjukkan bahwa besarnya price earning ratio (PER) pada perusahaan property dan real estate berpengaruh signifikan terhadap return saham, dan mengindikasikan bahwa investor memandang price earning ratio (PER) memiliki peranan dalam melakukan/ membuat keputusan investasi. Penelitian ini medukung penelitian Aydogan dan Gursoy (2002), dan penelitian Nainggolan (2004).

3. Variabel asset growth $(A G)$ berpengaruh positif dan tidak signifikan terhadap return saham. Hal ini menunjukkan bahwa besarnya asset growth $(A G)$ pada perusahaan property dan real estate berpengaruh tidak signifikan terhadap return saham, dan mengindikasikan bahwainvestormemandangassetgrowth ( $A G)$ tidak memiliki peranan dalam melakukan/ membuat keputusan investasi. Penelitian ini sejalan dengan penelitian Irianto Warsito (2003)

4. Variabel inflasi secara parsial berpengaruh positif dan signifikan terhadap return saham . Hal ini menunjukkan bahwa besarnya inflasi pada perusahaan property dan real estate berpengaruh signifikan terhadap return saham, dan mengindikasikan bahwa investor memandang inflasi memiliki peranan dalam melakukan/membuat keputusan investasi. Penelitian ini sejalan dengan dengan penelitian yang dilakukan yang dilakukan oleh tarazi dan gallato (2012) serta sari dan soytas (2005).

5. Hasil pengujian secara simultan dengan menggunakan semua variabel independen yaitu, return on equity (ROE), debt to equity ratio (DER), price earning ratio (PER), asset growth ( $A G)$, dan inflasi menunjukkan pengaruh secara signifikan dan simultan 
terhadap return saham perusahaan property dan real estate yang terdaftar pada bursa efek indonesia pada periode 2007 - 2012. Dari penelitian sebelumnya sepengetahuan penulis belum ada yang meneliti pengaruh return on equity (ROE), debt to equity ratio (DER), price earning ratio (PER), asset growth $(A G)$, dan inflasi terhadap return saham secara simultan.

\section{Daftar Pustaka}

Arifin, Ali. (2009). Membaca Saham, Edisi Ketiga, Cetakan Keempat. Yogyakarta: CV. Andi Offset.

Brigham., Eugene, F., \& Houston, Joel F. (2011). Essential of Financial Management, Jakarta: Salemba Empat

Bulzuardi, Aminudin. (2002). Pengaruh Rasio Keuangan Terhadap Harga Saham. Thesis Pascasarjana UI

Basu, S, 2011. "The Information Content of PriceEarnings Ratios." Financial Management 12.

Brigham., Eugene., F \& Joel F. Houston., (2010). Fundamentals Of Financial Management. 12th Edition Orlando: Harcourt Inc

Darmadji., Tjiptono., \& Fakhrudin, H. M. (2006). Pasar Modal Di Indonesia: Pendekatan Tanya Jawab. Jakarta: Salemba Empat

Ghozali, Imam, (2012). Aplikasi Analisis Multivariate dengan SPSS, BP. Semarang: Undip

Hadianto., Bram., \& Rony, S. (2007). Pengaruh volume perdagangan, EPS, dan PER terhadap harga saham sektor pertambangan periode 2000-2005 di BEJ, Jurnal Manajemen, Vol.7, No:1

Hanafi., Mamduh, M., \& Halim, A. (2009). Analisis laporan Keuangan. Edisi pertama. Cetakan Kedua. Yogyakarta: UPP AMP YKPN

Hartono. (2003). Teori Portofolio dan Analisis Investasi. Edisi ketiga. Yogyakarta: BPFE

Hartono., \& Jogiyanto. (2009). Teori Portofolio Dan Analisis Investasi. Yogyakarta: BPFE

Herlina., \& Hadianto. (2007). Pengaruh rasio fundamental terhadap harga saham sektor telekomunikasi periode 1997-2005 Di BEJ. Proceeding Seminar Nasional SMART Membaca Jaman Dalam Perspektif Manajemen. 99-116

Husnan., \& Suad. (2005). Dasar-Dasar Teori Portofoliodan Analisis Sekuritas. Yogyakarta: UPP:AMP YKPN

Jones., \& Charles. P, 2010. Investment: Analysis and Management. 8th edition. New York: John Wiley and Sons, Inc

Mais., Rini., \& Gusliana. (2005). Pengaruh Rasio -Rasio Keuangan Utama Perusahaan Terhadap Harga Saham Perusahaan Yang Terdaftar Di JII tahun 2004

Manao, H. \& Nur, D. (2001) “Asosiasi Rasio Keuangan dengan Return: Pertimbangan Ukuran Perusahaan Serta Pengaruh Krisis Ekonomi di Indonesia”. Simposium Nasional Akuntansi IV.

Meriewaty, D., \& Setyani, A. Y., (2005), "Analisis rasio keuangan terhadap perubahan kinerja pada perusahaan di industri food and beverages yang terdaftar di BEJ," Prosiding SNA VIII.

Minar S. (2009) Pengaruh Profitabilitas dan Rasio Leverage Keuangan Terhadap Return Saham pada Perusahaan Makanan dan Minuman Terbuka di Indonesia. Tesis. USU. Medan.

Purnomo., \& Yogo. (1998). Keterkaitan Kinerja Keuangan Dengan Harga Saham. Usahawan No:12 XXVII. Desember

Rahardjo., \& Mukti. (2007). Analisis tingkat suku bunga, kurs US\$ terhadap rupiah, dan inflasi dalam memprediksi harga saham pada sektor industri rokok di BEJ periode september 2001- september 2006. Jurnal Manajemen Tahun XI, No:2, Juni 2007

Sartono, A, (2010). Manajemen Keuangan (Teori dan Aplikasi), Edisi Enam, Yogyakarta.

Samsul, M, (2006). Pasar Modal \&Manajemen Portofolio. Jakarta: Erlangga

Sugiyono. (2009). Metode Penelitian Bisnis, Alfabeta : Bandung.

Sishariini., \& Nanik. (2003). Faktor-faktor yang mempengaruhi tingkat harga saham 
Eka, Suratno: Return on Equity, Debt to Equity Ratio...

perusahaan asuransi yang go public di BEJ. Jurnal Penelitian Ilmu-Ilmu Sosial. Volume XV No:2

Suharli., M., \& Oktorina, M., (2005), "Memprediksi Tingkat Pengembalian Investasi Pada Equity Securities Melalui Rasio Profitabilitas, Likuiditas, Dan Hutang Pada Perusahaan Publik Di Jakarta," Prosiding SNA VIII

Wijaya, L.R.P., Bandi, dan Wibawa, A., (2010), "Pengaruh Keputusan Investasi, Keputusan Pendanaan, dan Kebijakan Dividen Terhadap Nilai Perusahaan," Prosiding SNA XIII 